Original research article

\title{
Maternal health literacy of ethnic Hungarian mothers in Romania
}

\author{
Agnes-Rozsa Santha * \\ Sapientia Hungarian University of Transylvania, Faculty of Technical and Human Sciences, Department of Applied Social Sciences, Târgu Mureș, \\ Romania
}

\begin{abstract}
This study assesses health literacy of mothers with regard to the health of their children aged 10 or under. It measures the basic factual knowledge component of health literacy.

The sample size is 482 ethnic Hungarian mothers living in cities and villages in Transylvania, Romania. The research tool is a standardized online questionnaire. Respondents were asked to answer quiz-like questions, so health literacy scores were assigned to each respondent in all domains as well as a general score. Descriptive results reveal the health literacy in selected domains and population groups, and linear regression identifies the explanatory variables for health literacy disparities.

Altogether, the factual knowledge of mothers is in most cases at least acceptable. Linear regression reveals the impact of educational attainment and age when adjusted to covariates.

The differences in health literacy associated with social inequalities are revealed with respect to five domains out of six assessed with the online survey. The age of mothers shows positive correlation with their knowledge on child health. The results indicate the necessity of improving maternal health literacy, especially among low educated mothers.
\end{abstract}

Keywords: Educational attainment; Health literacy; Maternal age; Nutrition literacy; Social inequalities; Vaccine literacy

\section{Introduction}

The state of one's health is largely associated with health literacy. The consequences of low health literacy are harsh: poorer health status, less use of preventive services, increased hospitalization, longer recovery periods and increased mortality rates (Shih et al., 2016; Wolf et al., 2010). People with low health literacy have less knowledge about health outcomes, behaviours and health practices. In this way, health literacy is a contributing factor to health inequalities (Batterham et al., 2016).

It is known that health literacy serves as a mediator of health disparities. Low literacy in parents leads to detrimental health behaviour and poor health outcomes in their children. Both parent and child literacy are associated with important health outcomes, and health literacy is a mediating variable between parental and child health (DeWalt and Hink, 2009). Studies that measured child health literacy in different age groups have found that child obesity, for instance, especially at young ages, is mostly associated with parental factors (Chari et al., 2014). Lower parental health literacy, specifically reading comprehension, is associated with higher relapse rates among children with nephrotic syndrome and fewer of them achiev- ing complete remission. This fact underscores the importance of assessing and targeting health literacy for chronic management of childhood-onset diseases (Borges et al., 2017). Parental health literacy impacts their understanding of the child's diagnosis and treatment, so that parents displaying low health literacy rarely utilize the pediatric emergency care departments in hospitals (Morrison et al., 2013).

A systematic review of the literature concerning oral hygiene risk indicators concluded that parental education was one of the primary factors for the prediction of caries in primary teeth. A number of studies have concluded that higher education levels coincide with positive dental health and high levels of preventive care for the child (Park et al., 2016). Further, low parent health literacy is independently and significantly related to child sedentary lifestyle and child injury (Cheng et al., 2016), and with early childhood nutritional status (Johri et al., 2016).

However, in some special settings, no disadvantage was revealed in children coming from low health literate parents. For instance, such children engaged in and benefited from a family-based childhood obesity treatment program similar to children of parents with high literacy (Zoellner et al., 2017).

The focus of this paper is the assessment of health literacy of Hungarian mothers in Romania with respect to their under

\footnotetext{
* Author for correspondence: Agnes-Rozsa Santha, Sapientia Hungarian University of Transylvania, Faculty of Technical and Human Sciences, Department of Applied Social Sciences, Târgu Mureș, Romania; e-mail: santhaagnes@ms.sapientia.ro http://doi.org/10.32725/kont.2019.011
} 
age children. Out of the multiple dimensions of health literacy such as knowledge, functional, communicative, critical and motivational aspects (Sørensen et al., 2012), it is the knowledge component that is being subjected to analysis. The central research questions are in which domains of maternal health literacy are Hungarian mothers competent and in which of them do they lack knowledge, and also to what extent do socio-economic and demographic agents impact upon maternal health. The aim is to explain disparities in maternal health literacy across allegedly important inequality variables. A clear limitation of this study is that it does not allow for inferences to the factual health practices and behaviours, and that only ethnic minority Hungarian mothers are being studied from the Romanian population.

\section{Materials and methods}

The measurement tool was an online questionnaire (based on the standardised 2017 paper version of Semmelweis University in Budapest, Faculty of Medicine), entitled 'Parental health literacy questionnaire' (Gács et al., 2015). Questions on health literacy were used in exactly the same form as in the source questionnaire, and questions on socio-demographic features were added.

The online questionnaire was disseminated in the social media groupings of mothers in some regions of Transylvania, Romania: the counties of Harghita, Satu Mare, Cluj and Mures. The research population is those mothers who raise children aged 10 or under and who, according to their views, do most of the tasks related to the health of their children. The sample size is 482 . There are, methodologically, two limitations to the data collection. First, there is an evident bias in the sample; mothers with high educational attainment are overrepresented as the questionnaire was disseminated in social media groups among digitally literate mothers who are engaged in some kind of online discussions about child issues. Second, only mothers were questioned, and although they are the main caregivers in the vast majority of cases, no data is available on the rare situations where children are raised by their fathers.

The basic knowledge component of health literacy encompasses the following domains: transmission of infectious diseases, indicated use of antibiotics, hand hygiene, vaccine literacy in two domains: compulsory vaccines on the one hand and recommended vaccines and the causes of diseases on the other, and nutrition literacy (dietary recommendations in diarrhea disease). Knowledge in these domains was assessed with quiz-like questions, where correct answers were assigned the value 1 , incorrect answers the value 0 . There were 52 questions altogether. A general health literacy score was computed from these six elements, ranging from 0 to 52 . The questions assessing each domain of knowledge is described in the Appendix of this paper.

Our questionnaire also allows for the measurement of other dimensions of health literacy: functional health literacy (problem solving), motivations for finding genuine information on diseases and their treatment, and self-confidence about treatment of diseases and emergency situations, which could be the topic of future analysis.

In the data analysis, basic descriptive statistics are presented. Further, analysis of variance (ANOVA) and correlations reveal the main first-glance inequality dimensions in health literacy across the selected groups. Most variables along which basic descriptive statistics are performed are later included in a linear regression analysis, which assesses the explanatory power of variables one by one, adjusted for the effect of all other covariates, on the general maternal health literacy. Explanatory variables and their measurement levels are: age (continuous), educational attainment (ordinal), number of children (continuous), family structure (two parents or one parent) and settlement type (categorical).

Age is of a priori importance in health research and thus remains in the regression model throughout the whole model-building algorithm. The results of international studies are contradictory when it comes to the relationship between the age of mothers and their health literacy: some assess that older mothers have better knowledge on child health issues (Carolan, 2007), others find no effect on maternal age upon health literacy (Naghshineh et al., 2017).

In the literature, education was undoubtedly found to correlate both with health literacy (Jansen et al., 2018; Tiller et al., 2015) and with parental health literacy (Harrington et al., 2015). In our analysis we examined whether to use educational attainment as a continuous or categorical variable in the form of dummy variables. In the final regression (model) the ordinal variable was tested. Two models were fitted; in the first case the variable was used as continuous, in the second one as categorical variables using dummies. The more parsimonious model was chosen using the AIC information criteria indicator, so that in the final model, educational attainment was used in its original ordinal form.

Subjective socio-economic status was measured on a scale of 0 to 10 , employment relation was measured with the simple categories of working full time, working part time, being unemployed and being on maternal leave. However, these two variables are largely dependent on educational attainment and were therefore not included in the regression model.

Based on the findings of previous studies, family structure is supposed to impact upon health literacy (Howe and Winterhalter, 2013; Janisse et al., 2010; Kumar et al., 2014; Lorini et al., 2018). We approached family structure in the simplest way possible, namely whether a child is being raised by two parents or in a single-parent family. Given the purpose of this study, the legal foundation of a parental relationship was disregarded, and two-parent-families encompass both married and cohabiting couples raising children of their own, the children of one of them, or adopted children. We depart from the assumption that single parent-families are more at risk where the general health literacy, health behaviour and health outcomes of children are concerned (Kumar et al., 2014).

The number of children has a range from one to five or more. It is assumed that the more children a mother raises, the more knowledge she has on health related topics. Settlement type is a categorical variable with three values: villages, towns and cities.

During the regression analysis we aimed to find the best fitting and most parsimonious causal model, using the variable selection procedure. Following Kleinbaum et al. (2014), the model was first simplified leaving out the non-significant interaction effects one by one. Thereafter an automatized variable selection algorithm was used. Apart from age, the remaining variables were allowed to be sorted by the algorithm. Stepwise selection was used, setting the threshold at $5 \%$ for inclusion and at $10 \%$ for exclusion. The final model was subjected to multicollinearity diagnostics, monitoring the VIF and Tolerance indicators. 


\section{Results and discussion}

\section{The determinants of general maternal health literacy}

General maternal health literacy is measured on a scale ranging theoretically from 0 to 52 . The below histogram (Chart 1) shows a nearly perfect normal distribution of health literacy scores, with a mean of 37.31, a minimum value of 26 and a maximum of 46 . Altogether, the factual knowledge of mothers is in most cases at least acceptable; even the least knowledgeable mother had the correct answer to half of the questions she was asked.

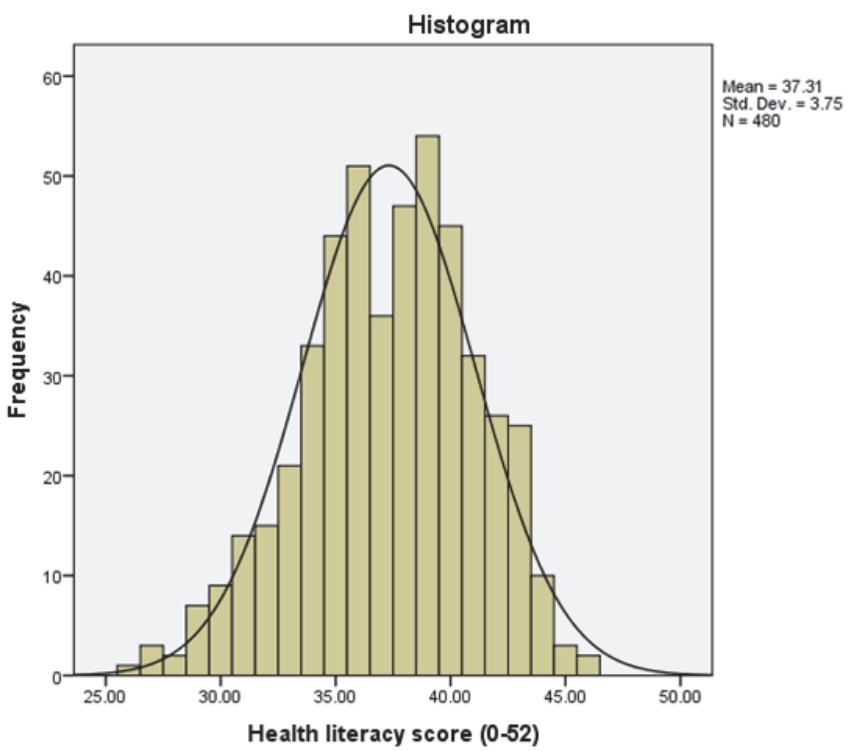

Chart 1. The distribution of general maternal health literacy score

As a first indicator of health literacy scores along selected groups of mothers, Table 1 shows the mean scores of health literacy. To assess whether there are significant differences in maternal health literacy across the most important socio-demographic categories, analysis of variance (ANOVA) is performed. Eta-squared measures two-variable associations and displays the percent of variance in health literacy scores explained by selected variables.

The results of the two-variable analysis between socio-demographic variables and general maternal health literacy in Table 1 reinforce some of our assumptions as well as the findings of previous international research. Mothers' low education produces lower levels of health literacy. Further significant differences are found with respect to employment status, number of underage children and settlement type. Mothers who work full-time attained the best health literacy scores, whereas with the increase in the number of children, there is also a slight increase in maternal health literacy in households with up to four children. Mothers with five or more children, however, know the least about the health issues of children. Maternal health literacy increases with the size of the settlement. Interestingly enough, although initially assumed and supported by findings of previous research (Kumar et al., 2014), the knowledge of mothers related to child health seems to be independent from family structure, so that single mothers do not score significantly lower on the health literacy scale. The measure of association (eta-squared) is for most variables very small. However, it reveals that maternal health
Table 1. General maternal health literacy score by socio-demographic categories (ANOVA), $N=482$

\begin{tabular}{|c|c|c|c|c|}
\hline & Mean & STD & $p$ & $\begin{array}{c}\text { Eta- } \\
\text { squared }\end{array}$ \\
\hline Sample total & 37.31 & 3.75 & & \\
\hline $\begin{array}{l}\text { Education } \\
\text { primary } \\
\text { lower secondary } \\
\text { secondary } \\
\text { tertiary }\end{array}$ & $\begin{array}{l}33.25 \\
33.37 \\
35.74 \\
38.14\end{array}$ & $\begin{array}{l}4.03 \\
3.39 \\
3.58 \\
3.43\end{array}$ & 0.000 & 0.149 \\
\hline $\begin{array}{l}\text { Employment status } \\
\text { maternity leave } \\
\text { unemployed/disabled } \\
\text { part-time } \\
\text { full time }\end{array}$ & $\begin{array}{l}36.67 \\
30.66 \\
36.88 \\
37.45\end{array}$ & $\begin{array}{l}4.35 \\
4.04 \\
3.83 \\
3.63\end{array}$ & 0.008 & 0.024 \\
\hline $\begin{array}{l}\text { Number of children } \\
1 \\
2 \\
3 \\
4 \\
5 \text { or more }\end{array}$ & $\begin{array}{l}37.15 \\
37.42 \\
37.43 \\
40.16 \\
29.00\end{array}$ & $\begin{array}{l}3.77 \\
3.67 \\
3.73 \\
2.92 \\
2.82\end{array}$ & 0.007 & 0.029 \\
\hline $\begin{array}{l}\text { Family structure } \\
\text { single parent } \\
\text { two parents }\end{array}$ & $\begin{array}{l}37.88 \\
37.28\end{array}$ & $\begin{array}{l}4.28 \\
3.72\end{array}$ & 0.439 & 0.001 \\
\hline $\begin{array}{l}\text { Settlement type } \\
\text { village } \\
\text { small town } \\
\text { city }\end{array}$ & $\begin{array}{l}36.40 \\
37.40 \\
38.17\end{array}$ & $\begin{array}{l}3.64 \\
3.30 \\
3.84\end{array}$ & 0.000 & 0.046 \\
\hline
\end{tabular}

literacy scores are weakly associated with employment status (eta-squared $=0.024$ ), the number of children in the household (eta-squared $=0.029$ ) and settlement type (eta-squared = 0.046), and moderately associated with educational attainment (eta-squared $=0.149)($ Table 2$)$.

Table 2. Correlation of general maternal health literacy with age and subjective socio-economic status, $N=482$

\begin{tabular}{lcc}
$\begin{array}{l}\text { General maternal health } \\
\text { literacy }\end{array}$ & $\begin{array}{c}\text { Pearson's correlation } \\
\text { coefficient }\end{array}$ & $p$ \\
age & $\mathbf{0 . 3 0 4}^{\mathrm{a}}$ & $\mathbf{0 . 0 0 0}$ \\
subjective socio-economic & $\mathbf{0 . 1 9 5}$ & $\mathbf{0 . 0 0 0}$ \\
status (1-10) & \\
\hline${ }^{\text {a } \text { Correlation is significant at the } 0.01 \text { level. }}$ & \\
\hline
\end{tabular}

Correlation coefficients were calculated for continuous variables and general health literacy scores. Economic status measured with the subjective perception of the individual's financial situation on a scale from 0 to 10 shows a weak correlation with health literacy, which comes as no surprise, as socio-economic status largely reflects educational attainment. The association of age with maternal health literacy is stronger and significant.

The results of the descriptive and two-variable analysis do not allow, however, for far-reaching conclusions, as relationships between variables might be spurious. The question of which variables impact individually upon maternal health literacy arises, and in order to identify the effect of explanatory variables adjusted to all covariates, a linear regression model is performed. Regression measures the impact of socio-demographic variables one by one upon the target variable general maternal health literacy controlling for other effects. All vari- 
ables were included in the linear regression in order to assess their controlled effect, except for the subjective financial status (which largely correlates with educational attainment).

Socio-demographic variables introduced in the regression model explain a total of $17.7 \%$ of the total variance of mater- nal health literacy, the F statistic is significant and neither VIF, nor tolerance values indicate multicollinearity among variables. Table 3 displays the model with the largest explanatory power and the variables with significant effects (Table 3).

Table 3. The social determinants of general maternal health literacy; linear regression, $N=482$

\begin{tabular}{|c|c|c|c|}
\hline Explanatory variables & Unstandardized $\beta$ & $p$ & Standardized $\beta$ \\
\hline age & 0.143 & 0.000 & 0.194 \\
\hline educational attainment (reference: low) & 1.875 & 0.000 & 0.316 \\
\hline family structure (reference: single parent) & -0.054 & 0.198 & \\
\hline type of settlement (reference: village) & 0.085 & 0.054 & \\
\hline number of children & -0.026 & 0.558 & \\
\hline (Constant) & 25.69 & 0.000 & \\
\hline Adjusted $R^{2}=17.7 ; F=51.65 ; p=0.000$ & & & \\
\hline
\end{tabular}

Observing the absolute Beta $(\beta)$ values it can be stated that educational attainment has the most powerful effect upon maternal health literacy $(\beta=0.316)$, followed by age $(\beta=0.194)$. Apart from these two, no other variable that previously in the two-variable analyses (ANOVA) was associated with disparities, has a significant impact when adjusted to the covariates in the linear regression.

Interpreting the data it can be stated that educational attainment causes significant and massive differences: compared to those with elementary school qualification only, an increase by one educational level means almost a two point increase on the health literacy scale $(\beta=1.875)$. Mothers with university degrees score as many as $(4-1)^{*} 1.875=5.625$ points more on the health literacy scale than mothers with low education. The advantage of high education for health literacy is evident. Independently of other differences, the educational attainment of mothers has the most significant effect, so that the health literacy scores of educated mothers are much higher than the results of those with lower education - all other conditions being the same. In previous international studies, health literacy was positively associated with educational level, net household income and self-perceived social position (Tiller et al., 2015), and studies attest that parent health literacy also correlates with these (Harrington et al., 2015).

The impact of educational attainment is followed by the impact of maternal age. Health literacy is positively associated with age. An increase of one year in the age leads to a slight improvement $(\beta=0.143)$ in health literacy. Age is a predictor of a priori importance in health research, and it has also proven to significantly impact on health literacy within this specific sample of mothers. Given similar social conditions and educational attainment, an older mother is more knowledgeable of the child health issues than a younger one.

Age has a well-established place in health research, but mostly in relation with the state of health, and health worsens with age. Age impacts on maternal health literacy in the opposite way. Correlation analysis has revealed a positive association of age and health literacy, that is, better scores for older mothers, and linear regression has reinforced the beneficial impact of age on the knowledge of child health issues. In the literature on health literacy, there is some indication that health literacy might, to some extent, improve with age. Studies from the Netherlands, former Eastern Germany and Japan predicted health knowledge in line with our findings - in that it increases with age (Nakayama et al., 2015; Tiller et al., 2015; van der Heide et al., 2013). In the recent past, Naghshineh et al. (2017) found age to be non-significant for maternal health literacy in some domains like girls' puberty health. However, an earlier US-research revealed positive correlation between age and maternal health literacy and this was due to the fact that older mothers tend to overconsume health information; they know too much and are even lost in the information (Carolan, 2007). Our results point toward this latter direction. The age of a mother significantly affects her maternal health literacy independently of educational attainment. That is, between two mothers with the same education, the older one knows more about child health than the younger.

The number of children in the household does not show a linear association with maternal health literacy. In the two-variable variance analysis (ANOVA) there was a slight increase in health literacy until four children households. Then, the knowledge of mothers with five or more children was drastically lower. Most probably, having many children in the household is associated with low socio-economic status and lower levels of health literacy.

Despite our well-founded assumption, family structure does not explain maternal health literacy differences. A systematic review of scientific articles identified family structure as important for a child's oral health: children raised by single parents had worse outcomes and poorer oral health compared to children from multi-adult households (Kumar et al., 2014). The same goes for parental health literacy in international research, where limited parent health literacy has been associated with single parenthood (Howe and Winterhalter, 2013; Janisse et al., 2010). However, in our specific sample of Hungarian mothers in Romania, single mothers are not disadvantaged in their knowledge on child-related health issues compared to those raising the children with their spouses.

Nor does the settlement type set forth significant disparities in maternal health literacy (although such differences were revealed in the two-variable analyses). When controlled for educational attainment, the impact of these allegedly significant explanatory variables disappears.

\section{Domains of maternal health literacy}

We measured general maternal health literacy with a scale computed from six separate domains of knowledge. We now take a closer look at these components one by one. The range of the variables differs, as knowledge in the different topics was assessed with quiz-like questions differing in number (Table 4 and 5). 
Table 4. Domain-specific health literacy scores by socio-demographic categories (ANOVA), $N=482$

\begin{tabular}{|c|c|c|c|c|c|c|c|c|c|}
\hline & \multicolumn{3}{|c|}{$\begin{array}{l}\text { Infectious disease transmission } \\
(0-7)\end{array}$} & \multicolumn{3}{|c|}{$\begin{array}{l}\text { Indicated use of antibiotics } \\
\qquad(0-6)\end{array}$} & \multicolumn{3}{|c|}{$\begin{array}{l}\text { Hand hygiene } \\
(0-3)\end{array}$} \\
\hline & Mean & STD & $p$ & Mean & STD & $p$ & Mean & STD & $p$ \\
\hline Sample total & $\begin{array}{c}5.46 \\
(78 \%)\end{array}$ & 0.68 & & $\begin{array}{c}5.11 \\
(85.16 \%)\end{array}$ & 1.13 & & $\begin{array}{c}2.16 \\
(72 \%)\end{array}$ & 0.61 & \\
\hline $\begin{array}{l}\text { Education } \\
\text { primary } \\
\text { lower secondary } \\
\text { secondary } \\
\text { tertiary }\end{array}$ & $\begin{array}{l}4.25 \\
5.17 \\
5.38 \\
5.53\end{array}$ & $\begin{array}{l}0.50 \\
0.75 \\
0.66 \\
0.67\end{array}$ & 0.000 & $\begin{array}{l}3.25 \\
3.31 \\
4.72 \\
5.40\end{array}$ & $\begin{array}{l}2.06 \\
1.39 \\
1.12 \\
0.88\end{array}$ & 0.000 & $\begin{array}{l}1.99 \\
2.21 \\
2.03 \\
2.75\end{array}$ & $\begin{array}{l}0.61 \\
0.73 \\
0.59 \\
0.50\end{array}$ & 0.004 \\
\hline $\begin{array}{l}\text { Employment status } \\
\text { maternity leave } \\
\text { unemployed/disabled } \\
\text { part-time } \\
\text { full-time }\end{array}$ & $\begin{array}{l}5.37 \\
5.00 \\
5.37 \\
5.48\end{array}$ & $\begin{array}{l}0.69 \\
1.00 \\
0.68 \\
0.68\end{array}$ & 0.372 & $\begin{array}{l}4.69 \\
3.33 \\
5.07 \\
5.17\end{array}$ & $\begin{array}{l}1.38 \\
1.52 \\
1.14 \\
1.08\end{array}$ & 0.002 & $\begin{array}{l}2.16 \\
2.00 \\
2.22 \\
2.15\end{array}$ & $\begin{array}{l}0.65 \\
1.00 \\
0.64 \\
0.61\end{array}$ & 0.968 \\
\hline $\begin{array}{l}\text { Number of children } \\
\quad 1 \\
2 \\
3 \\
4 \\
5 \text { or more }\end{array}$ & $\begin{array}{l}5.34 \\
5.55 \\
5.58 \\
5.66 \\
4.50\end{array}$ & $\begin{array}{l}0.70 \\
0.66 \\
0.68 \\
0.51 \\
0.70\end{array}$ & 0.002 & $\begin{array}{l}5.01 \\
5.18 \\
5.30 \\
5.50 \\
1.50\end{array}$ & $\begin{array}{l}1.20 \\
1.04 \\
1.07 \\
0.83 \\
0.70\end{array}$ & 0.000 & $\begin{array}{l}2.17 \\
2.15 \\
2.13 \\
2.16 \\
2.00\end{array}$ & $\begin{array}{l}0.61 \\
0.62 \\
0.54 \\
0.75 \\
1.41\end{array}$ & 0.988 \\
\hline $\begin{array}{l}\text { Family structure } \\
\text { single parent } \\
\text { two parents }\end{array}$ & $\begin{array}{l}5.44 \\
5.47\end{array}$ & $\begin{array}{l}0.50 \\
0.69\end{array}$ & 0.831 & $\begin{array}{l}5.08 \\
5.11\end{array}$ & $\begin{array}{l}1.22 \\
1.13\end{array}$ & 0.876 & $\begin{array}{l}2.12 \\
2.16\end{array}$ & $\begin{array}{l}0.72 \\
0.61\end{array}$ & 0.914 \\
\hline $\begin{array}{l}\text { Settlement type } \\
\text { village } \\
\text { small town } \\
\text { city }\end{array}$ & $\begin{array}{l}5.31 \\
5.46 \\
5.61\end{array}$ & $\begin{array}{l}0.76 \\
0.69 \\
0.57\end{array}$ & 0.000 & $\begin{array}{l}4.85 \\
5.11 \\
5.36\end{array}$ & $\begin{array}{l}1.26 \\
1.03 \\
0.98\end{array}$ & 0.000 & $\begin{array}{l}2.06 \\
2.19 \\
2.23\end{array}$ & $\begin{array}{l}0.60 \\
0.59 \\
0.63\end{array}$ & 0.048 \\
\hline
\end{tabular}

Table 5. Domain-specific health literacy scores by socio-demographic categories (ANOVA), $N=482$

\begin{tabular}{|c|c|c|c|c|c|c|c|c|c|}
\hline & \multicolumn{3}{|c|}{$\begin{array}{c}\text { Compulsory vaccines } \\
(0-14)\end{array}$} & \multicolumn{3}{|c|}{$\begin{array}{l}\text { Recommended vaccines and } \\
\text { causes of diseases }(0-13)\end{array}$} & \multicolumn{3}{|c|}{$\begin{array}{l}\text { Dietary recommendations in } \\
\text { diarrhea disease }(0-9)\end{array}$} \\
\hline & Mean & STD & $p$ & Mean & STD & $p$ & Mean & STD & $p$ \\
\hline Sample total & $\begin{array}{c}10.21 \\
(72.92 \%)\end{array}$ & & & $\begin{array}{c}7.70 \\
(59.23 \%)\end{array}$ & 1.27 & & $\begin{array}{c}6.65 \\
(73.88 \%)\end{array}$ & 0.97 & \\
\hline $\begin{array}{l}\text { Education } \\
\text { primary } \\
\text { lower secondary } \\
\text { secondary } \\
\text { tertiary }\end{array}$ & $\begin{array}{c}9.25 \\
8.58 \\
9.61 \\
10.53\end{array}$ & $\begin{array}{l}2.50 \\
2.12 \\
1.78 \\
1.84\end{array}$ & 0.000 & $\begin{array}{l}7.50 \\
7.27 \\
7.50 \\
7.80\end{array}$ & $\begin{array}{l}0.55 \\
1.64 \\
1.29 \\
1.22\end{array}$ & 0.042 & $\begin{array}{l}6.25 \\
7.00 \\
6.54 \\
6.65\end{array}$ & $\begin{array}{l}0.95 \\
0.80 \\
1.09 \\
0.92\end{array}$ & 0.128 \\
\hline $\begin{array}{l}\text { Employment status } \\
\text { maternity leave } \\
\text { unemployed/disabled } \\
\text { part-time } \\
\text { full-time }\end{array}$ & $\begin{array}{c}10.11 \\
6.66 \\
9.85 \\
10.27\end{array}$ & $\begin{array}{l}2.19 \\
2.08 \\
2.05 \\
2.09\end{array}$ & 0.022 & $\begin{array}{l}7.53 \\
7.33 \\
7.70 \\
7.72\end{array}$ & $\begin{array}{l}1.29 \\
0.57 \\
1.53 \\
1.25\end{array}$ & 0.761 & $\begin{array}{l}6.79 \\
6.33 \\
6.66 \\
6.63\end{array}$ & $\begin{array}{l}1.38 \\
1.52 \\
1.14 \\
1.08\end{array}$ & 0.740 \\
\hline $\begin{array}{l}\text { Number of children } \\
1 \\
2 \\
3 \\
4 \\
5 \text { or more }\end{array}$ & $\begin{array}{r}10.12 \\
10.21 \\
10.41 \\
11.83 \\
8.50\end{array}$ & $\begin{array}{l}2.17 \\
2.08 \\
2.03 \\
1.72 \\
2.12\end{array}$ & 0.233 & $\begin{array}{l}7.75 \\
7.70 \\
7.47 \\
8.33 \\
7.00\end{array}$ & $\begin{array}{l}1.23 \\
1.27 \\
1.42 \\
1.03 \\
1.41\end{array}$ & 0.438 & $\begin{array}{l}6.75 \\
6.60 \\
6.52 \\
6.66 \\
5.50\end{array}$ & $\begin{array}{l}0.96 \\
1.01 \\
0.80 \\
0.81 \\
0.70\end{array}$ & 0.185 \\
\hline $\begin{array}{l}\text { Family structure } \\
\text { single parent } \\
\text { two parents }\end{array}$ & $\begin{array}{l}10.92 \\
10.17\end{array}$ & $\begin{array}{l}2.13 \\
2.11\end{array}$ & 0.086 & $\begin{array}{l}7.56 \\
7.71\end{array}$ & $\begin{array}{l}1.15 \\
1.28\end{array}$ & 0.551 & $\begin{array}{l}6.76 \\
6.64\end{array}$ & $\begin{array}{l}1.01 \\
0.97\end{array}$ & 0.572 \\
\hline $\begin{array}{l}\text { Settlement type } \\
\text { village } \\
\text { small town } \\
\text { city }\end{array}$ & $\begin{array}{c}9.80 \\
10.33 \\
10.55\end{array}$ & $\begin{array}{l}2.05 \\
1.92 \\
2.20\end{array}$ & 0.000 & $\begin{array}{l}7.62 \\
7.70 \\
7.78\end{array}$ & $\begin{array}{l}1.31 \\
1.33 \\
1.20\end{array}$ & 0.447 & $\begin{array}{l}6.72 \\
6.58 \\
6.60\end{array}$ & $\begin{array}{l}0.90 \\
0.99 \\
1.03\end{array}$ & 0.363 \\
\hline
\end{tabular}


The domains of knowledge reveal unequal knowledge of mothers in different topics. The best-known among these are the effects of antibiotics: mothers scored highest (85.16\%) on questions regarding the indicated use of antibiotics in child healthcare. Meanwhile, the least correct answers were given on the recommended vaccines (such as the HPV vaccine) and the causes of some diseases (59.23\%).

Knowledge differences mostly echo educational attainment inequalities. However, in the case of nutrition literacy, although the average knowledge score is not the highest, no significant differences are revealed along socio-demographic categories. That is, mothers with low educational attainment and unfavorable social status know just as much about what kind of diet is recommended for the child as those with high education. This finding is one of the few unexpected outcomes from our analysis as it contradicts the evidence of international studies on the association between education and nutrition literacy (Doustmohammadian et al., 2018; Speirs et al., 2012).
In all other domains, mother's education is significantly related to her knowledge on health issues, and in some cases, employment status, number of children and settlement type (these being in themselves often related to educational attainment). Family structure produces no significant disparities in maternal knowledge in any of the six domains. Based on the existing literature (Howe and Winterhalter, 2013; Janisse et al., 2010; Kumar et al., 2014; Lorini et al., 2018), we assumed that single-mother families would be at increased risk of limited health literacy in all domains compared to those with two present parents. However, our results refute this assumption.

It has been shown above that general maternal health literacy correlated with age and socio-economic status. In a more detailed analysis, the scores obtained by respondents in each specific knowledge domain were then subject to correlation analysis, as shown in the table below (Table 6).

\section{Table 6. Correlations of domain-specific health literacy with age and subjective socio-economic status, $N=482$}

\begin{tabular}{|c|c|c|c|c|c|}
\hline Infectious disease transmission & $\begin{array}{l}\text { Pearson's correlation } \\
\text { coefficient }\end{array}$ & $p$ & Indicated use of antibiotics & $\begin{array}{c}\text { Pearson's correlation } \\
\text { coefficient }\end{array}$ & $p$ \\
\hline age & $0.244^{b}$ & 0.000 & age & $0.343^{b}$ & 0.000 \\
\hline subjective socio-economic status $(1-10)$ & $0.105^{a}$ & 0.021 & $\begin{array}{c}\text { subjective socio-economic } \\
\text { status }(1-10)\end{array}$ & $0.175^{b}$ & 0.000 \\
\hline Hand hygiene & $\begin{array}{l}\text { Pearson's correlation } \\
\text { coefficient }\end{array}$ & $p$ & Compulsory infant vaccines & $\begin{array}{l}\text { Pearson's correlation } \\
\text { coefficient }\end{array}$ & $p$ \\
\hline age & 0.073 & 0.111 & age & $0.236^{\mathrm{b}}$ & 0.000 \\
\hline subjective socio-economic status (1-10) & $0.163^{b}$ & 0.000 & $\begin{array}{l}\text { subjective socio-economic } \\
\text { status }(1-10)\end{array}$ & $0.163^{b}$ & 0.000 \\
\hline $\begin{array}{l}\text { Recommended vaccines and causes } \\
\text { of diseases }\end{array}$ & $\begin{array}{l}\text { Pearson's correlation } \\
\text { coefficient }\end{array}$ & $p$ & Nutrition literacy & $\begin{array}{l}\text { Pearson's correlation } \\
\text { coefficient }\end{array}$ & $p$ \\
\hline age & 0.011 & 0.807 & age & 0.021 & 0.649 \\
\hline subjective socio-economic status (1-10) & 0.071 & 0.119 & $\begin{array}{l}\text { subjective socio-economic } \\
\text { status }(1-10)\end{array}$ & -0.042 & 0.358 \\
\hline
\end{tabular}

Three of the health literacy domains are associated with both subjective socio-economic status and age of the mother: knowledge on infectious disease transmission, on the indicated antibiotics use and compulsory infant vaccine literacy. Knowledge on hand hygiene correlates with socio-economic status only, whereas recommended vaccine literacy is not associated with either of these two variables.

Nutrition literacy is a topic of maternal health literacy which, unlike the other domains and unlike in other parts of the world (Doustmohammadian et al., 2018; Speirs et al., 2012), remains independent of the existing social and demographic inequalities among mothers. Here, parental knowledge is most homogeneous.

\section{Conclusions}

This study provides new insights into the mechanisms by which socio-economic and demographic factors influence maternal health literacy with regard to child health. Some allegedly important predictors like the number of children, family structure and settlement type do not impact upon maternal health literacy in themselves, whilst others lead to considerable differences. Most importantly, there are immense differences between mothers with low and high education, and between younger and older mothers. Educational and social inequalities produce large inequalities in maternal health literacy, so that only nutrition literacy is independent from the socio-economic situation of mothers.

The analysis reinforced the role of cultural capital widely recognized to be associated with health literacy in general and maternal health literacy in particular. We consider that the key finding of our study is assessing the improvement of maternal health literacy with age.

\section{Conflict of interests}

The author has no conflict of interests to declare.

\section{Acknowledgement}

I am grateful to the Semmelweis University Pediatrical Clinic II and to the research group led by Dr. Zsófia Gács for allowing me to use their validated questionnaire on parental health literacy. 


\section{Zdravotní gramotnost mad'arských matek v Rumunsku}

\section{Souhrn}

Tato studie hodnotí zdravotní gramotnost matek s ohledem na zdraví svých dětí ve věku od 10 let nebo méně. Měří základní složku věcných poznatků o zdravotní gramotnosti.

Velikost vzorku tvoři 482 etnických mad'arských matek žijících v městech a obcích v Transylvánii v Rumunsku. Byl použit standardizovaný on-line dotazník. Respondentky byly požádány, aby odpověděly na kvízové dotazy, takže skóre zdravotní gramotnosti bylo přiděleno každé respondentce ve všech oblastech, stejně jako celkové skóre. Popisné výsledky odhalují zdravotní gramotnost ve vybraných oblastech a populačních skupinách a lineární regrese určuje vysvětlující proměnné pro rozdily v oblasti zdravotní gramotnosti.

Faktické znalosti matek jsou ve většině případů přinejmenším přijatelné. Lineární regrese odhaluje vliv dosaženého vzdělání a věku, když je přizpůsobena náhodným proměnným.

Rozdíly ve zdravotní gramotnosti spojené se sociálními nerovnostmi jsou odhaleny s ohledem na pět domén ze šesti, které byly vyhodnoceny pomocí on-line průzkumu. Věk matky vykazuje pozitivní korelaci se znalostmi o dětském zdraví. Výsledky naznačují nutnost zlepšit zdravotní gramotnost - zejména u matek s nízkou úrovní vzdělání.

Klíčová slova: mateřský věk; očkovací gramotnost; sociální nerovnost; úroveň vzdělání; výživová gramotnost; zdravotní gramotnost

\section{References}

1. Batterham RW, Hawkins M, Collins PA, Buchbinder R, Osborne RH (2016). Health literacy: applying current concepts to improve health services and reduce health inequalities. Public Health 132: 3-12. DOI: 10.1016/j.puhe.2016.01.001.

2. Borges K, Sibbald C, Hussain-Shamsy N, Vasilevska-Ristovska J, Banh T, Patel V, et al. (2017) Parental health literacy and outcomes of childhood nephrotic syndrome. Pediatrics 139(3): 1-9. DOI: 10.1542/peds.2016-1961.

3. Carolan M (2007). Health literacy and the information needs and dilemmas of first-time mothers over 35 years. J Clin Nurs 16(6): 1162-1172. DOI: 10.1111/j.1365-2702.2007.01600.x.

4. Chari R, Warsh J, Ketterer T, Hossain J, Sharif I (2014). Association between health literacy and child and adolescent obesity. Patient Educ Couns 94(1): 61-66. DOI: 10.1016/j. pec.2013.09.006.

5. Cheng ER, Bauer NS, Downs SM, Sanders LM (2016). Parent health literacy, depression, and risk for pediatric injury. Pediatrics 138(1): e 20160025.

6. DeWalt D, Hink A (2009). Health literacy and child health outcomes: A systematic review of literature. Pediatrics 124(3): 265-274. DOI: 10.1542/peds.2009-1162B.

7. Doustmohammadian A, Keshavarz Mohammadi N, Omidvar N, Amini M, Abdollahi M, Eini-Zinab H, et al. (2018). Food and nutrition literacy (FNLIT) and its predictors in primary schoolchildren in Iran. Health Promot Int. DOI: 10.1093/ heapro/day050.

8. Gács Zs, Berend K, Csanády G, Csizmady A (2015). A new questionnaire for assessing parental health literacy. Orv Hetil 156(42): 1715-1718. DOI: 10.1556/650.2015.30237.

9. Harrington KF, Zhang B, Magruder T, Bailey WC, Gerald LB (2015). The impact of parent's health literacy on pediatric asthma outcomes. Pediatr Allergy Immunol Pulmonol 28(1): 20-26. DOI: 10.1089/ped.2014.0379.

10. Howe CJ, Winterhalter E (2013). Parent health literacy: risks and outcomes. J Pediatr Nurs 28(5): 515-516. DOI: 10.1016/j. pedn.2013.06.001.

11. Janisse HC, Naar-King S, Ellis D (2010). Brief report: Parent's health literacy among high-risk adolescents with insulin dependent diabetes. J Pediatr Psychol 35(4): 436-440. DOI: 10.1093/jpepsy/jsp077.

12. Jansen T, Rademakers J, Waverijn G, Verheij R, Osborne R, Heijman M (2018). The role of health literacy in explaining the association between educational attainment and the use of outof-hours primary care services in chronically ill people: A survey study. BMC Health Serv Res 18(1): 394. DOI: 10.1186/s12913018-3197-4.
13. Johri M, Subramanian SV, Koné GK, Dudeja S Chandra D, Minoyan N, et al. (2016). Maternal health literacy is associated with early childhood nutritional status in India. J Nutr 146(7): 1402-1410. DOI: 10.3945/jn.115.226290.

14. Kleinbaum D, Kupper L, Nizam A, Rosenberg ES (2014). Applied regression analysis and other multivariable methods, 5 th ed. Boston: Cengage Learning.

15. Kumar S, Kroon J, Lalloo R (2014). A systematic review of the impact of parental socio-economic status and home environment characteristics on children's oral health related quality of life. Health Qual Life Outcomes 12: 41. DOI: 10.1186/1477-7525-12-41.

16. Lorini C, Santomauro F, Donzellini M, Capecchi L, Bechini A, Boccalini S, et al. (2018). Health literacy and vaccination: A systematic review. Human Vaccin Immunother 14(2): 478-488. DOI: $10.1080 / 21645515.2017 .1392423$.

17. Morrison AK, Myrvik MP, Brousseau DC, Hoffmann RG Stanley, RM (2013). The relationship between parent health literacy and pediatric emergency department utilization: A systematic review. Acad Pediatr 13(5): 421-429. DOI: 10.1016/j acap.2013.03.001.

18. Naghshineh E, Golshiri P, Sichani ZH (2017). Knowledge of mothers about puberty health in girls: A survey in the center of Iran. IJTMGH 5(3): 102-106. DOI: 10.15171/ijtmgh.2017.21.

19. Nakayama K, Osaka W, Togari T, Ishikawa H, Yonekura Y, Sekido A, et al. (2015). Comprehensive health literacy in Japan is lower than in Europe: a validated Japanese-language assessment of health literacy. BMC Public Health 15: 505. DOI: 10.1186/s12889-015-1835-x.

20. Park J-B, Han K, Park Y-G, Ko Y (2016). Association between socioeconomic status and oral health behaviors: The 2008-2010 Korea national health and nutrition examination survey. Exp Ther Med 12(4): 2657-2664. DOI: 10.3892/etm.2016.3679.

21. Shih S-F, Liu C-H, Liao L-L, Osborne RH (2016). Health literacy and the determinants of obesity: a population-based survey of sixth grade school children in Taiwan. BMC Public Health 16: 280. DOI: 10.1186/s12889-016-2879-2.

22. Sørensen K, Van den Broucke S, Fullam J, Doyle G, Pelikan J, Slonska Z, et al. (2012). Health literacy and public health: A systematic review and integration of definitions and models. BMC Public Health 12: 80. DOI: 10.1186/1471-2458-12-80.

23. Speirs KE, Messina LA, Munger AL, Grutzmacher SK (2012). Health literacy and nutrition behaviors among low-income adults. J Health Care Poor Underserved 23(3): 1082-1091. DOI: 10.1353/hpu.2012.0113.

24. Tiller D, Herzog B, Kluttig A, Haertin J (2015). Health literacy in an urban elderly East-German population - results from the population-based CARLA study. BMC Public Health 15: 883. DOI: 10.1186/s12889-015-2210-7. 
25. van der Heide I, Rademakers J, Schipper M, Droomers M, Sørensen K, Uiters E (2013). Health literacy of Dutch adults: a cross sectional survey. BMC Public Health 13: 179. DOI: 10.1186/1471-2458-13-179.

26. Wolf MS, Feinglass J, Thompson J, Baker DW (2010). In search of 'low health literacy': Threshold vs. gradient effect of literacy on health status and mortality. Soc Sci Med 70(9): 1335-1341. DOI: 10.1016/j.socscimed.2009.12.013.
27. Zoellner JM, Hill J, You W, Brock D, Frisard M, Alexander R, Silva F, et al. (2017). The influence of parental health literacy status on reach, attendance, retention, and outcomes in a family-based childhood obesity treatment program, Virginia, 2013-2015. Prev Chronic Dis 14: E87. DOI: 10.5888/ pcd14.160421.

\section{Appendix}

\section{Questionnaire items measuring maternal health literacy}

\section{Knowledge on infectious diseases transmission}

Imagine the following situation: The child of your neighbour is ill, but your child wants to play with him/her. Which are the diseases that allow for playing together, because they will definitely not infect your child?

\begin{tabular}{|c|l|c|}
\hline & Disease type & Correct answer: allowed \\
\hline 1 & flu & \\
\hline 2 & lice & $\mathrm{X}$ \\
\hline 3 & renal (kidney) inflammation & $\mathrm{X}$ \\
\hline 4 & anemia & \\
\hline 5 & inflammation of the conjunctiva & $\mathrm{X}$ \\
\hline 6 & dry chickenpox (varicella) rashes & \\
\hline 7 & diarrhea, vomiting some hours before & \\
\hline
\end{tabular}

\section{Knowledge on the indicated use of antibiotics}

Below are some statements about antibiotics. Which are correct?

\begin{tabular}{|r|l|c|}
\hline & Statement & Correct answer: true \\
\hline 8 & When the child has a temperature, antibiotics are needed. & \\
\hline 9 & Sore throat is always caused by bacteria. & X \\
\hline 10 & Antibiotics are not efficient for infections by viruses. & \\
\hline 11 & It is enough to take antibiotics until symptoms disappear. & \\
\hline 13 & $\begin{array}{l}\text { Influenza can be cured with antibiotics. } \\
\text { disease; there is no need to go to the doctor. }\end{array}$ & \\
\hline
\end{tabular}

\section{Knowledge on hand hygiene}

Which of the following diseases can be fought efficiently with a thorough hand wash?

\begin{tabular}{|l|l|c|}
\hline & Disease type & Correct answer \\
\hline 14 & diarrhea and vomiting caused by viruses (ex. rotavirus) & $\mathrm{X}$ \\
\hline 15 & leuchaemia & \\
\hline 16 & hepatitis B (infectious liver inflammation) & \\
\hline
\end{tabular}




\section{Knowledge on compulsory vaccines}

Which are the diseases against which your child gets a compulsory vaccine?

\begin{tabular}{|c|l|c|}
\hline & Disease type & Correct answer: vaccine is compulsory \\
\hline 17 & tuberculosis & $\mathrm{X}$ \\
\hline 18 & scarlet fever & $\mathrm{X}$ \\
\hline 19 & poliomyelitis & $\mathrm{X}$ \\
\hline 20 & diphtheria & $\mathrm{X}$ \\
\hline 21 & pertussis & $\mathrm{X}$ \\
\hline 22 & malaria & \\
\hline 23 & measles & $\mathrm{X}$ \\
\hline 24 & Lyme's disease & $\mathrm{X}$ \\
\hline 25 & tetanus & \\
\hline 26 & hepatitis A & \\
\hline 27 & hepatitis B & \\
\hline 28 & diarrhea/vomiting caused by rotavirus & \\
\hline 29 & chickepox (varicella) & \\
\hline 30 & HPV (human papilloma virus) & \\
\hline
\end{tabular}

Knowledge on the causes of diseases and on recommended vaccines

Please decide whether the following statements are true or not:

\begin{tabular}{|c|c|c|c|}
\hline & Statement & $\begin{array}{l}\text { Correct answer: } \\
\text { true }\end{array}$ & $\begin{array}{l}\text { Correct answer: } \\
\text { false }\end{array}$ \\
\hline 31 & Diseases with diarrhea and vomiting are always caused by bad food. & & $\mathrm{X}$ \\
\hline 32 & Young children endure dehydration much better than adults. & & $\mathrm{X}$ \\
\hline 33 & Vaccine against rotavirus is not an injection, but a drop to be orally administered. & $\mathrm{X}$ & \\
\hline 34 & $\begin{array}{l}\text { The biggest risk of chickenpox/varicella is that the scratched bells leave permanent } \\
\text { cicatrices behind. }\end{array}$ & & $\mathrm{x}$ \\
\hline 35 & Chickenpox/varicella is most dangerous for boys. & $\mathrm{X}$ & \\
\hline 36 & $\begin{array}{l}\text { The vaccine against chickenpox/varicella offers protection for the period of childhood } \\
\text { against the severe side-effects of the disease. }\end{array}$ & $\mathrm{X}$ & \\
\hline 37 & A HPV/human papillomavirus can cause cancer in boys and men, too. & $\mathrm{X}$ & \\
\hline 38 & $\begin{array}{l}\text { If a girl marries as a virgin, she will not get infected with sexually transmittable diseases, } \\
\text { as only prostitutes get infected. }\end{array}$ & & $\mathrm{X}$ \\
\hline 39 & HPV/human papillomavirus vaccine reduces the risk of cervical cancer in women. & $\mathrm{X}$ & \\
\hline 40 & $\begin{array}{l}\text { One of the most frequent side-effects of vaccines is the tumefaction or pain on the locus } \\
\text { of the administration. }\end{array}$ & $\mathrm{x}$ & \\
\hline 41 & A temperature is one of the most frequent side-effects of vaccines. & $\mathrm{x}$ & \\
\hline 42 & HPV vaccine causes autoimmune disease. & & $\mathrm{X}$ \\
\hline 43 & HPV vaccine can be administered even if a person is already sexually active. & $\mathrm{X}$ & \\
\hline
\end{tabular}

\section{Knowledge on the dietary recommendations for those with diarrhea}

Your child has diarrhea and had laxity 3 or 4 times during the day. Which foods is he/she allowed to eat?

\begin{tabular}{|c|l|c|}
\hline & Food type & Correct answer: allowed \\
\hline 44 & grapes & \\
\hline 45 & apple & \\
\hline 46 & banana & $\mathrm{X}$ \\
\hline 47 & dry biscuits & \\
\hline 48 & cooked potato & \\
\hline 49 & hamburger & $\mathrm{X}$ \\
\hline 50 & rice & $\mathrm{X}$ \\
\hline 51 & dark chocolate & \\
\hline 52 & cooked vegetables & \\
\hline
\end{tabular}

